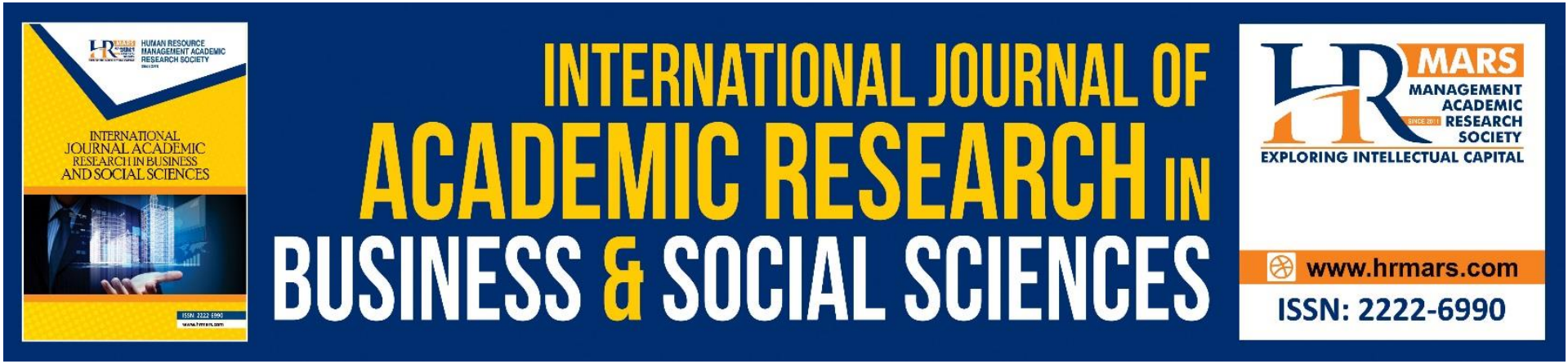

\title{
A Knight Without Shining Armour: The Paradox of Being a Gig Worker in Malaysia
}

Salmie Jemon, Mohd Safri Saiman, Mohammad Puad Bebit, Mohd Ali Hindia

To Link this Article: http://dx.doi.org/10.6007/IJARBSS/v11-i11/11175 DOI:10.6007/IJARBSS/v11-i11/11175

Received: 04 September 2021, Revised: 28 September 2021, Accepted: 20 October 2021

Published Online: 03 November 2021

In-Text Citation: (Jemon et al., 2021)

To Cite this Article: Jemon, S., Saiman, M. S., Bebit, M. P., \& Hindia, M. A. (2021). A Knight Without Shining Armour: The Paradox of Being a Gig Worker in Malaysia. International Journal of Academic Research in Business and Social Sciences, 11(11), $262-269$.

\section{Copyright: @ 2021 The Author(s)}

Published by Human Resource Management Academic Research Society (www.hrmars.com)

This article is published under the Creative Commons Attribution (CC BY 4.0) license. Anyone may reproduce, distribute, translate and create derivative works of this article (for both commercial and non-commercial purposes), subject to full attribution to the original publication and authors. The full terms of this license may be seen at: http://creativecommons.org/licences/by/4.0/legalcode

Vol. 11, No. 11, 2021, Pg. $262-269$

Full Terms \& Conditions of access and use can be found at http://hrmars.com/index.php/pages/detail/publication-ethics 


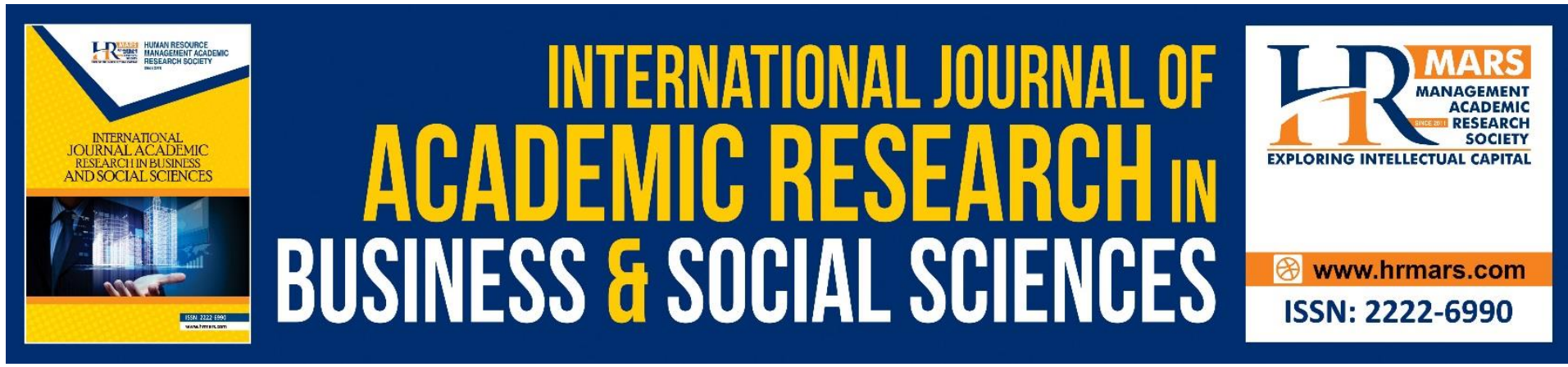

\title{
A Knight Without Shining Armour: The Paradox of Being a Gig Worker in Malaysia
}

\author{
Salmie Jemon ${ }^{1}$, Mohd Safri Saiman², Mohammad Puad Bebit ${ }^{3}$, \\ Mohd Ali Hindia ${ }^{4}$ \\ ${ }^{1}$ Faculty of Social Sciences and Humanities, Universiti Malaysia Sabah, ${ }^{2}$ Faculty of Business, \\ Economics and Accountancy, Universiti Malaysia Sabah, ${ }^{3}$ Academy of Art and Creative \\ Technology, Universiti Malaysia Sabah, ${ }^{4}$ The Social Security Organisation, Sabah \\ Email: salmie@ums.edu.my
}

\begin{abstract}
Studies on social security in Malaysia can be traced way back to the early years of the 2000s and have become even more dynamically interesting as the world economy is open to new ideas, challenges, and vast potential. The labour market, especially in developing and emerging economies are, prior to the devastative worldwide pandemic of COVID19, entangled with the sad but true impacts of the Industrial Revolution 4.0. Unfortunately, yet interestingly, the former seemed likely to have wider economic impacts and implications for labour-related issues across the globe, not excluding Malaysia. This short article analyses an updated overview of social security in Malaysia as the pandemic goes through a series of oscillating waves of cases experienced by countries worldwide.
\end{abstract}

Keywords: Digital Transformation, Social Security, Gig Workers, Self-Employed, COVID-19

\section{Introduction}

The way society does things has changed and transformed tremendously since the First Industrial Revolution. Fast forward and we are now amid the Fourth Wave of such a revolution that has again changed how we work in society as part of the whole economic system. The Internet of Things (IOT) has created a new simplicity and convenience in how goods and services are delivered to the market. As a result of the digitalization of the labour market, there is a surge in new types of self-employment and multiple job holding (Kenney et al., 2019). Among others, gig workers are worthy of being highlighted as they are not only the byproduct of the digital transformation but also are the segment of the society that is impacted by the pandemic. Nonetheless, the impact of the pandemic and partial lockdown bears different consequences for the different groups of gig workers in Malaysia. With the stay-athome orders, there was an increasing demand for food delivery services, while e-hailing and taxi drivers lost customers.

The gig economy is defined as the demand and supply of short-term or task-based working activities that are matched through online labour platforms (De Stefano, 2015). Work on digital platforms can be differentiated into online-web based and local app-based platforms 
(Berg et al., 2018). Schmidt (2017) has coined the term 'cloud work' and 'gig work'; Cloud work is a web-based, entirely digital form of on-demand labour in which tasks are accomplished behind a computer from anywhere in the world. The term 'gig work' refers to tasks that are conducted offline, in a specific area, and are mediated to a select group of people and a crowd via a platform or a work-on-demand app (Kidd, 2020). According to Malaysia Digital Economy Corporation (MDEC) estimates, there will be 700,000 workers in the gig economy by the end of 2020. However, only two out of every ten gig economy occupations are online-based, such as programmer positions, with the rest being location-based, such as e-hailing services (Abdullah, 2021). This article will delve more into the second category - gig work-based on location - with a focus on labour protection in Malaysia.

\section{Gig Work and Social Security Protection in Malaysia}

The traditional definition of a standard employment relationship refers to the legal link that constitutes reciprocal rights and obligations between employers and employees as stipulated in labour law. Gig work does not encompass such elements, they are dependent on selfemployment, inevitably fall outside of the realms of the standard employment relationship. In addition, labour platforms are not officially employers, hence there is no obligation to provide any fringe benefits for their gig workers.

Workers in the gig economy are classified as independent contractors under the Malaysia Employment Act 1955, which defines them as "individuals employed or appointed under a Contract for Service merely to work on a specific project or job for the purposes of the principal's trade or business." Malaysia advocates the employment-based social protection strategy thus self-employment is not covered by the social security scheme. This is what Cherry (2021) coined as the 'essential worker paradox'. Although the role of gig workers was acknowledged as vital during the pandemic, the law considered them as falling beyond the scope of employment protection. Due to the intricacies of the legislation governing employment categorization, gig workers have been denied employment status and associated advantages, such as a minimum wage, the opportunity to join a union, and basic statutory benefits.

Despite the lack of labour law protections, the Malaysia Social Security Organization (SOCSO) has taken the initiative to widen the scope of social security to those who are self-employed with the establishment of the Self-Employment Social Security Scheme Act (SESSS). Commencing in June 2017, the scheme provides social security protection designated for those self-employed as stated in the Passenger Transportation Sector, such as self-employed taxi, e-hailing, and bus drivers. In 2020, SESSS extends its coverage to 19 other self-employed sectors as listed in Table 1: 
TABLE 1

\begin{tabular}{|l|l|}
\hline 1. Good \& Food Transport & 11. Food \\
\hline 2. Online Business & 12. Support Services \\
\hline 3. Agriculture & 13. Manufacturing \\
\hline 4. Information Technology & 14. Arts \\
\hline 5. Livestock & 15. Construction \\
\hline 6. Data Processing & 16. Household Services \\
\hline 7. Forestry & 17. Hawkers \\
\hline 8. Agents & 18. Accommodation Premises \\
\hline 9. Fisheries & 19. Beauty\& Healthcare \\
\hline 10. Professional Services & \\
\hline
\end{tabular}

Source: The Social Security Organization, Malaysia (2021)

This scheme provides protection and financial compensation to self-employed insured persons and their dependents against work-related ailments, including occupational diseases and accidents. Figure 1 depicts the scheme's benefits:

\section{BENEFITS}
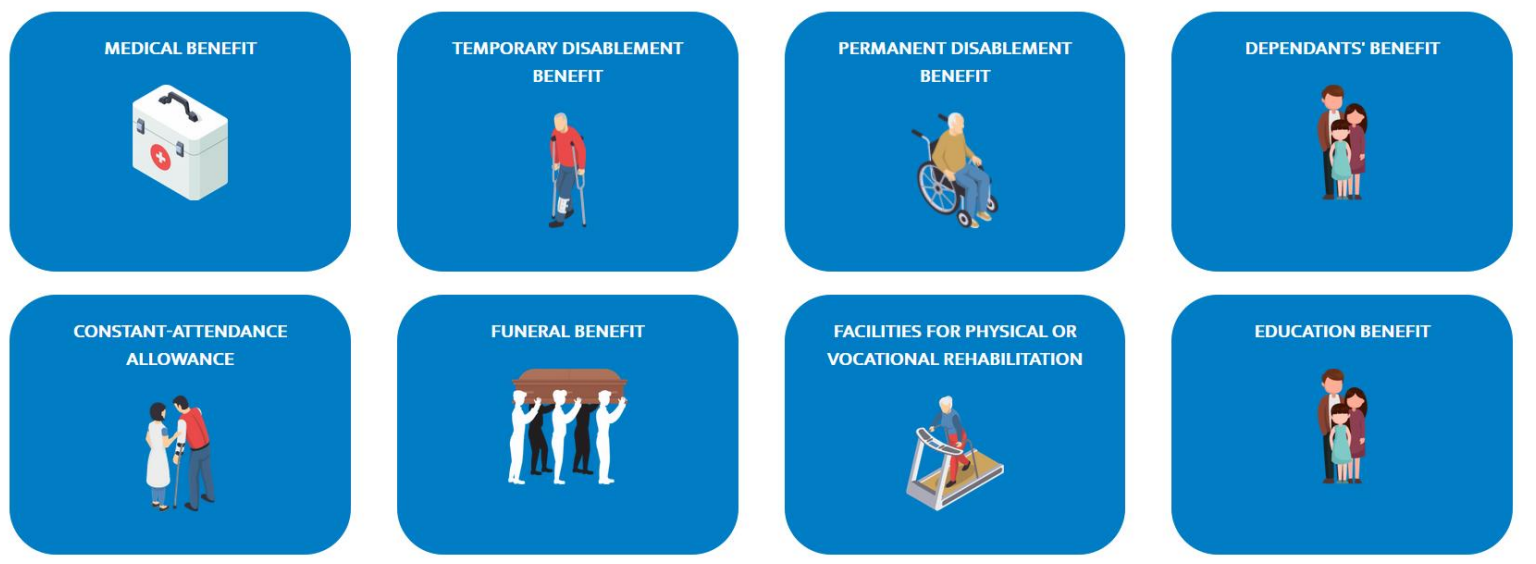

Figure 1

Source: The Social Security Organization Malaysia (2021)

The combined effect of pandemics may be damaging to the economic fabric, and the immediate responses cannot separate its impact on those working in the informal sector. To promote the gig economy and provide a social safety net, the government has allocated RM50 million in funds to the gig economy platforms via SOCSO PenjanaGig and the Employees Provident Fund's (EPF) i-Saraan scheme (National Economic Recovery Plan, 2020). For gig workers, the SESSS contribution plan for a coverage period of one year is RM232.80, in which the government contributes 70\% (RM163) while the remaining 30\% (RM69.80) is contributed by the labour platform (or their own gig employees through the platform service provider). The SESSS contribution schedule is detailed in Table 2. 
TABLE 2:

Schedule of Contributions

\begin{tabular}{|c|c|c|c|c|}
\hline No. & $\begin{array}{l}\text { Insured } \\
\text { Earning }\end{array}$ & Monthly & $\begin{array}{l}\text { Monthly } \\
\text { Contribution }\end{array}$ & Annual Contribution \\
\hline 1 & RM1,050 & & RM13.10 & RM157.20 \\
\hline 2 & RM1,550 & & RM19.40 & $\begin{array}{l}\text { RM232.80 } \\
\text { (Gig Workers Contribution Plan) }\end{array}$ \\
\hline 3 & RM2,950 & & RM36.90 & RM442.80 \\
\hline 4 & RM3,950 & & RM49.40 & RM592.80 \\
\hline
\end{tabular}

Source: The Social Security Organization, Malaysia (2021)

Additional initiatives to provide social protection coverage for gig workers include the Skim Pekerjaan Sendiri Lindung (SPSLindung) assistance as cited in the Budget 2021 announcement made in Parliament on November 6, 2020. Under the PERMAI package, announced in January 2021 , the government will fully contribute to delivery riders' social protection coverage under SESSS with an initial target of 40,000 beneficiaries (Employment Injury Scheme, 2020). Delivery riders refer to those who are self-employed and conduct the delivery of goods and food items using a motorcycle, bicycle, or by walking. Data from the Ministry of Human Resources shows that as of July 2021, there were already 88,847 workers registered with a total of RM 21.08 million in paid contributions (MOHR Initiatives Managing Covid-19 Pandemic, 2021)

Old-age income security is also imperative, though this is not always the privilege extended to gig workers under the normal labour law employment relationship. Nevertheless, the voluntary-based retirement incentive i-Saraan scheme (via The Employment Provident Fund) provides self-employed (traders, gig economy, housewives, e-hailing, and taxi drivers) aged under 55 years with benefits comparable to those in regular jobs. In addition to the workers' own contributions, the government contributes 15\%, up to a maximum of RM250 per year, under i-Saraan (KWSP - EPF Voluntary Contribution - i-Saraan, 2020). Grab Malaysia, overwhelmed with 50,000 people joining them during the COVID-19 pandemic, is one of the eminent labour platform providers in Malaysia that supports the old-age income security initiatives by encouraging their drivers and delivery partners to save for their retirement via the EPF's i-Saraan programme. They provide incentives such as an additional $5 \%$ contribution (maximum RM80) per year and 10\% (maximum RM120) for those classified as Persons with Disabilities (PWDs) across all age groups (The Edge Markets, 2021).

After discussing the foregoing, the discussion turned to our preliminary field study among gig workers in Kota Kinabalu, Sabah, which began in August 2021. Due to the early-stage nature of this study, the preliminary findings may be inconclusive and require further investigation, 
but this will provide insights into potential issues that warrant further focused study. According to the preliminary pilot survey, 24 out of 31 respondents did not have personal insurance coverage for healthcare, accidents, or illness. 22 respondents also did not enrol in SOCSO's social security protection scheme, despite the fact that the contribution is heavily subsidised by the government. This revealed an alarming trend. What happens if the government no longer provides subsidies after the contract expires? Will they contribute voluntarily to the scheme, or should a mandatory contribution policy be imposed on all gig workers? This could imply that stagnant social security coverage is the result of rational choice by workers and their households, rather than worker myopia or a lack of information.

\section{Conclusion}

The global pandemic crisis poignantly reveals the gaps in safeguarding the self-employed. We highlight that the role of gig workers was acknowledged as vital during the pandemic, however the law considered them as falling beyond the scope of employment protection. Recent findings from Denmark, Germany, and the United Kingdom indicate that the reliability of self-employed insurance benefits in comparison to one-off state payments or business loans (Jerg et al., 2021). In Malaysia, the heavily subsidised insurance contributions for selfemployed people are only a short-term solution to deal with the pandemic's aftereffects. There were no permanent changes to the labour and social security laws.

Fighting for workers' rights has been the mantra for ages. As put forward by Marx, it will be a never-ending class struggle between the bourgeoisie and proletariat. A work is still a work, whether the task is completed over the cloud system or performed physically. We should expect hiccups in defining and classifying the legal terms of what constitutes work and the extent of its protection to workers as a result of the ever-changing nature of work, technological innovation, and dynamic and drastic changes in the labour market. The rules and regulation are created by humans, so it should be adaptable to reflect current needs.

Notwithstanding the COVID-19 pandemic, it has served as a catalyst for new policy-related social security protection in Malaysia, particularly for self-employed individuals, through the introduction of new social security schemes under the existing flagship of worker protection. Proactive efforts by the Malaysian government in handling and tackling the ongoing pandemic are highly commendable and appreciated. Nevertheless, to make sure that social security is a successful policy in Malaysia, transparent and well-implemented action is the key to reaching out to those self-employed gig workers. They are part of the labour market as a whole and play an integral role in the whole system of the economy, especially during extraordinary and abnormal times like those witnessed during the COVID-19 pandemic. In light of these immediate shocks, as well as the longer-term structural changes implied by the digitalization of employment, there is a need for a renewed social protection paradigm, shifting from a charity-based model to a more universal rights-based approach.

Looking forward into the future of 'back-to-normal' is what is optimistically anticipated by all nations affected and overwhelmed by such a historic pandemic. Building comprehensive social protection systems with strong, nationally appropriate social protection floors is fundamental to promoting sustainable and solid social security (Behrendt et al., 2019). In the case of Malaysia, it has been marked as one of the most challenging periods faced in the modern history of our country. Nevertheless, the crucial lesson that can be drawn from such 
an unfortunate anomaly is the readiness to cope and adapt to future unexpected events, which we can all agree by now will be more challenging economically, socially, and politically.

\section{Recommendations}

Based on the findings and discussion above, the following are recommendations that could be considered pertaining the special category of gig workers' social security in terms of labour protection in Malaysia.

- The study recommended that more research be conducted in the future, particularly on the inclusion of gig workers in the social security system, as this type of work is expected to be a permanent feature in the coming decades.

- Appropriate guidelines and policies by the government should be properly enacted to avoid irregularities and injustices in terms of social security.

- An extended study on the impact of gig workers' livelihoods as a way forward in the post-COVID era.

\section{Acknowledgement}

The authors would like to express their gratitude to Universiti Malaysia Sabah (UMS) for their assistance with the research and publication processes. This study was part of a larger project funded by the UMS internal research grant SDK297-202.

\section{References}

Abdullah, A. H. (2021). Gig economy workers - the ones left behind / The Malaysian Insight. The Malaysian Insight. https://www.themalaysianinsight.com/s/327083

Behrendt, C., Nguyen, Q. A., \& Rani, U. (2019). Social protection systems and the future of work: Ensuring social security for digital platform workers. International Social Security Review, 72(3), 17-41. https://doi.org/10.1111/issr.12212

Berg, J., Furrer, M., Harmon, E., Rani, U., \& Silberman, M. S. (2018). Digital labour platforms and the future of work Towards decent work in the online world. https://www.ilo.org/wcmsp5/groups/public/---dgreports/---dcomm/--publ/documents/publication/wcms_645337.pdf

De Stefano, V. (2015). The Rise of the "Just-in-Time Workforce": On-Demand Work, Crowd Work and Labour Protection in the "Gig-Economy." SSRN Electronic Journal. https://doi.org/10.2139/ssrn.2682602

Employment Injury Scheme. (2020). https://belanjawan2021.treasury.gov.my/manfaat/index.php/bm/sps-lindung

Jerg, L., O'Reilly, J., \& Buschoff, K. S. (2021). Adapting social protection to the needs of multiple jobholders in Denmark, the United Kingdom and Germany. Transfer, 27(2), 237253. https://doi.org/10.1177/1024258921991039

Kenney, M., Rouvinen, P., Seppälä, T., \& Zysman, J. (2019). Industry and Innovation Platforms and industrial change Platforms and industrial change. https://doi.org/10.1080/13662716.2019.1602514

Kidd, S. C. (2020). Conceptualizing the Gig Economy in Malaysia. In Research for Social Advancement (Issue 7). https://refsa.org/wp-content/uploads/2020/06/REFSA-BriefConceptualising-the-Gig-Economy-in-Malaysia.pdf

KWSP - EPF Voluntary Contribution - i-Saraan. (2020). https://www.kwsp.gov.my/member/contribution/i-saraan 
MOHR Initiatives Managing Covid-19 Pandemic. (2021). Ministry of Human Resources. https://www.mohr.gov.my/images/flipbook/inisiatifKSM/mobile/index.html\#p=1.

Schmidt, F. A. (2017). Digital Labour Markets in the Platform Economy: Mapping the Political Challenges of Crowd Work and Gig Work. Freidrich Ebert Stiftung, January, 1-32. https://library.fes.de/pdf-files/wiso/13164.pdf

The Edge Markets. (2021). https://www.theedgemarkets.com/article/epf-signs-mouencourage-grab-drivers-delivery-partners-signing-isaraan-selfcontribution

The Social Security Organization Malaysia. (2021). https://www.perkeso.gov.my/en/ 